\title{
Institutional Conditions for Strengthening the Position of Organic Farming as a Component of Sustainable Development
}

\author{
Instytucjonalne uwarunkowania wzmocnienia pozycji \\ rolnictwa ekologicznego jako elementu \\ rozwoju zrównoważonego
}

\author{
Władysława Łuczka \\ Faculty of Economic, University of Life Sciences in Poznań \\ ul. Wojska Polskiego 28, 60-637 Poznań, Poland \\ E-mail: wladyslawa.luczka@up.poznan.pl,ORCID: 0000-0002-1997-8119
}

\begin{abstract}
In recent years, the development of organic farming has slowed down, especially in the European Union. This is a factor of importance for sustainable development prospects of the agricultural sector. Although the European Union places more and more emphasis on environmental goals set under the Common Agricultural Policy, twothirds of the agricultural budget in the 2014-2020 financial perspective are allocated to support conventional farming. In 2014-2018, some member countries witnessed stagnation or decline in the area of organic farmland. This means that in the context of market imperfections - and in the absence of valuation of public goods - microeconomic costs incurred by organic farmers continue to exceed the benefits they reap. The level of support must be high enough to stimulate the development of organic farming in the long run. Therefore, it is recommended that the future support mechanism provide financial encouragement for organic farming, revise the principles for granting payments, tighten the system, and minimize the amount of payments decoupled from production volumes.
\end{abstract}

Key words: sustainable development, organic farming, institutions, support

\section{Streszczenie}

W ostatnich latach nastąpiło spowolnienie dynamika rozwoju rolnictwa ekologicznego, zwłaszcza w Unii Europejskiej, co ma znaczenie dla przyszłych perspektyw rozwoju zrównoważonego w rolnictwie. Chociaż Unia Europejska przywiązuje coraz większe znaczenie do realizacji celów środowiskowych w ramach Wspólnej Polityki Rolnej, to jednak 2/3 środków budżetu rolnego w perspektywie finansowej na lata 2014-2020 zostało przeznaczonych na wsparcie rolnictwa konwencjonalnego. Niektóre kraje członkowskie odnotowały w latach 2014-2018 pewną stagnację powierzchni rolnictwa ekologicznego lub spadek. Oznacza to, że w sytuacji niedoskonałości rynku i braku wyceny dóbr publicznych, mikroekonomiczne koszty ponoszone przez rolników ekologicznych są w dalszym ciągu wyższe od uzyskiwanych korzyści. Poziom wsparcia musi być na tyle wysoki, aby stymulował rozwój rolnictwa ekologicznego w długim okresie. Dlatego wskazane jest, aby w przyszłym mechanizmie wsparcia nastąpiło finansowe wzmocnienie rolnictwa ekologicznego i jednoczesne zrewidowanie zasad przyznawania płatności oraz uszczelnienie systemu i zminimalizowanie zjawiska płatności oderwanych od produkcji.

Słowa kluczowe: rozwój zrównoważony, rolnictwo ekologiczne, instytucje, wsparcie 


\section{Introduction}

Implementing sustainable development requires a redefinition and reorientation of key goals and management methods of many sectors. This is particularly important in sectors where economic processes are strongly dependent on the natural environment. These sectors include agriculture which plays a special environmental role due to the direct impact of agricultural production on ecosystems, food safety and, in broader terms, on the condition of rural areas. Agricultural development has long been based on the maximization of economic benefits (profits or incomes) at the expense of the disequilibrium in the ecological and social system. In highly developed countries, that agricultural model was stimulated by an agricultural policy which supported the quantitative growth of agricultural production (Stoate et al., 2009). This resulted in agricultural practices becoming more and more intensive, while also driving excessive supply of food and environmental degradation (Czyżewski, Staniszewski, 2018).

In order to reduce the environmental degradation, agriculture must be viewed as a sector which enables the operation of different methods of natural resource management, including not only those based on the primacy of economic efficiency criteria, but also alternative options underpinned by a rational use of natural resources. One of the key arguments for the new model of agriculture, one which enables the operation of farming systems which differ in goals and characteristics, is the need to restrain the negative environmental impacts of industrial farming (Tittonell, 2014). Another important argument is the need for increasing the role of agriculture as a sector that provides not only market goods but also public goods such as environmental wellbeing, biodiversity and rural viability. This means reorienting the agricultural development model based on the primacy of economic efficiency criteria towards sustainable agriculture which has many functions to fulfill: economic functions (ensuring acceptable incomes to agricultural producers), social functions (ensuring employment, quality of living, landscape values) and environmental functions (preserving biodiversity and the quality of soil, air and water). Only a sustainable agriculture model based on the integrality of economic, social and environmental goals has the greatest capacity to deliver the desired public goods (external environmental benefits).

An inherent part of sustainable agriculture is organic farming which, in addition to manufacturing highquality food based on sustainable plant and animal production processes, also delivers environmental public goods such as landscape, biodiversity and quality of natural resources (Niggli, 2015). The key principle of organic farming is the informed decision to no longer rely on agricultural, veterinary and food chemicals in food manufacturing processes, and to replace them with natural substances and measures in order to preserve economic sustainability. By activating environmental production mechanisms, the organic system ensures sustainable soil fertility, animal health and high-quality agricultural products. The exclusion of pesticides and industrially processed fertilizers from production processes, together with sustainable animal farming, are practices which do not result in atmospheric, soil and groundwater pollution.

As it delivers public goods, organic farming is and should be supported under the public policy which has adequate regulatory and financial tools to stimulate that sector's development. In recent years, the development of organic farming has slowed down, especially in the European Union. This is a factor of importance for sustainable development prospects of the agricultural sector and rural areas. Hence, the purpose of this paper is to answer the question on how much is the slowdown in organic farming development related to institutional conditions, and what changes are required to counteract that process in the future. This paper is based on a critical review of the literature and on data published by FiBL, the Swiss Research Institute of Organic Agriculture which owns the largest database on organic farming.

\section{Organic farming as a source of public goods}

Organic farming is an important element in the implementation of sustainable development principles because it delivers not only private goods (such as high-quality organic food) but also environmental public goods. The delivery of private goods is regulated by the free market, unlike it is the case for public goods which are not governed by market mechanisms. The market neither values not produces public goods in sufficient quantities. In turn, the absence of valuation of public goods results in a situation where no one is encouraged to deliver them. The characteristics of public goods are non-competitiveness and non-excludability. Non-competitiveness means that the use (or consumption) of public goods does not restrict other people's ability to use them (non-rivalry in consumption) (Stiglitz, 1986; Samuelson, Nordhaus, 2012; Aocella, 2002; Altvater, 2007). In turn, non-excludability means that there are no practical ways for excluding an individual from the consumption of a public good, or that the exclusion would be possible only at a great cost (Stiglitz, 1986).

From the perspective of institutional economics, public goods are a specific case of externalities because their producers deliver them not only to themselves but also to other actors (Aocella, 2002). This is the consequence of the gap between private costs and social benefits generated by economic operators. Therefore, it provides room for an active public policy which may affect the way they are delivered. The absence of state intervention could result in a situa- 
tion where a specific goods is not produced despite great demand for it (Wojtyna, 1990; Stiglitz, 1986).

Even though the problem of public goods has been addressed in the literature since the 1950s, research on environmental public goods in the agriculture (including in organic farming) has been initiated only recently. There is lack of comprehensive research on supply of and demand for public goods because of the complexity of numerous indicators and valuation methods used (Hall et al., 2004; Unnevehr, 2004). Furthermore, there is no clear classification of environmental public goods, although the following types are usually listed in the relevant literature: agricultural landscape, farmland biodiversity, water quality and availability, soil functionality, climatic stability (carbon emissions, greenhouse gas emissions, atmospheric quality, resilience to flooding and fire).

The research on the contribution of organic farming to the generation of public goods is usually carried out at farm level (the farms being grouped by type, size, location and management method) rather than at sector level. According to such research projects, organic farming is a source of goods which specifically include landscape, biodiversity, natural environment, human health and welfare, animal health and welfare, energy and climate (Bengtsson et al., 2005; Cooper et al., 2010; Stolze et al., 2009; Tuomisto et al., 2012). Interesting findings came from a Danish study intended to determine the effects of the ban on the use of synthetic pesticides in organic plant production and of the restrictive limitation of antibiotics used in organic animal production (Jespersen et al., 2017, p. 246). The study found that organic farming has a clearly positive impact on the generation of public goods such as nature, biodiversity and human and animal health and welfare. However, its impact on the environment, energy and climate is heterogeneous and depends on the type, size, management method and location of the farm. The dominant view presented in the relevant literature is that organic farming is guided by high environmental standards and therefore has the greatest potential to deliver public goods and should be the point of focus for the agricultural policy (Brodzińska, 2015).

\section{Importance of institutional support in stimu- lating the development of organic farming}

At its initial stage, the unique feature of organic farming was the fact that farmers who believed in the primacy of environmental values over economic values shifted to organic farming methods based on a bottom-up approach without any public support. At that time (1970s and 1980s), organic farming was more a social movement backed up by a strong ideological dimension rather than an important form of management. Although it had a minor economic sig- nificance, it played a major role as a social movement which provided a new alternative for mainstream agriculture (de Buck et al., 2001; Michelsen et al., 2001; Midmore et al., 2001). That period was marked by a strong activity of national and international organic farmers' associations. They played a key role in formulating the first standards of organic farming which provided a basis for the relevant legal regulations that followed. The consumer's growing interest in and demand for organic food contributed to growth in the organic food market.

In the European Union, organic farming remained outside the area of interest of the agricultural policy until the 1990s. Introduced in 1992, legal regulations on organic farming standards and on indications referring to organic products (Council Regulation No. 2092/91) provided an important stimulus for the development of organic farming. Especially in European Union countries, it contributed to the unification of regulations applicable to organic farming, production, distribution and marking.

Another important factor initiated with the 1992 MacSharr'y reform was financial support for organic farming and other environmental measures taken in the agricultural sector. Public funds transferred to agriculture increasingly became a payment for the farmer's efforts made to enhance the natural environment and landscape, or a compensation for benefits (income) lost due to these efforts. One decade after the introduction of organic farming subsidies, European Union countries started to implement the European Action Plan for Organic Food and Farming, as adopted by the European Commission in 2004 (European Commission, 2004). The Plan emphasizes the importance of the potential behind and benefits from the organic production system (especially with respect to environmental protection and animal welfare), and its potential benefits for rural development.

Both of these processes (i.e. standardization induced by the government and financial support) testified to the political acceptance of organic farming, initially in the European Union and, later on, in other countries. The role of organic farming in the delivery of environmental public goods was the key argument for countries who decided to provide it with support. Although organic farming plays an important role in implementing the principles of sustainable development due to its potential in the delivery of environmental public goods, the area of organic farmland is decisive for its actual importance. If the area of organic farmland is small in relation to the total area of agricultural land, organic farming can be an activity of minor significance. According to available data resources, the area of organic farmland around the world was 11 million ha $(0.3 \%)$ in 1999 , and grew to reach 71.5 million ha in 2018 but had a small share in total agricultural land (barely 1.5\%). See Figure 1. 


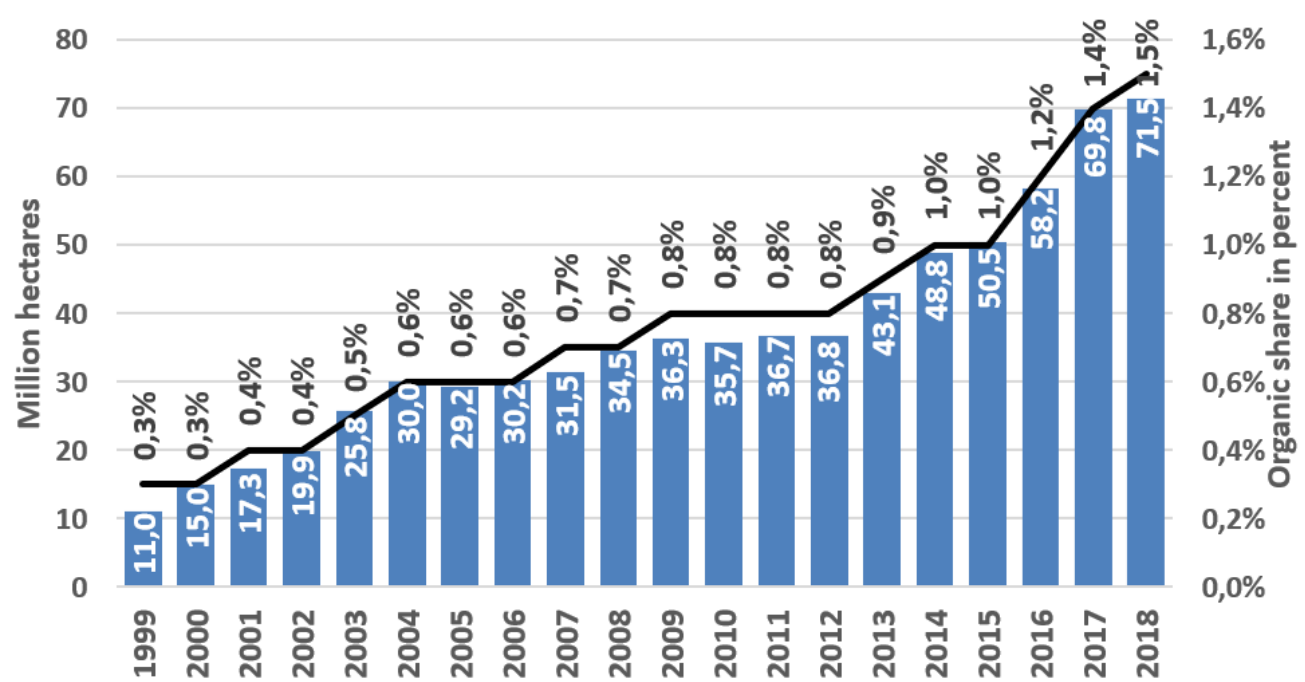

Figure 1. Share of organic farming in total agricultural land around the world in 1999-2017, source: Willer et al., 2020.

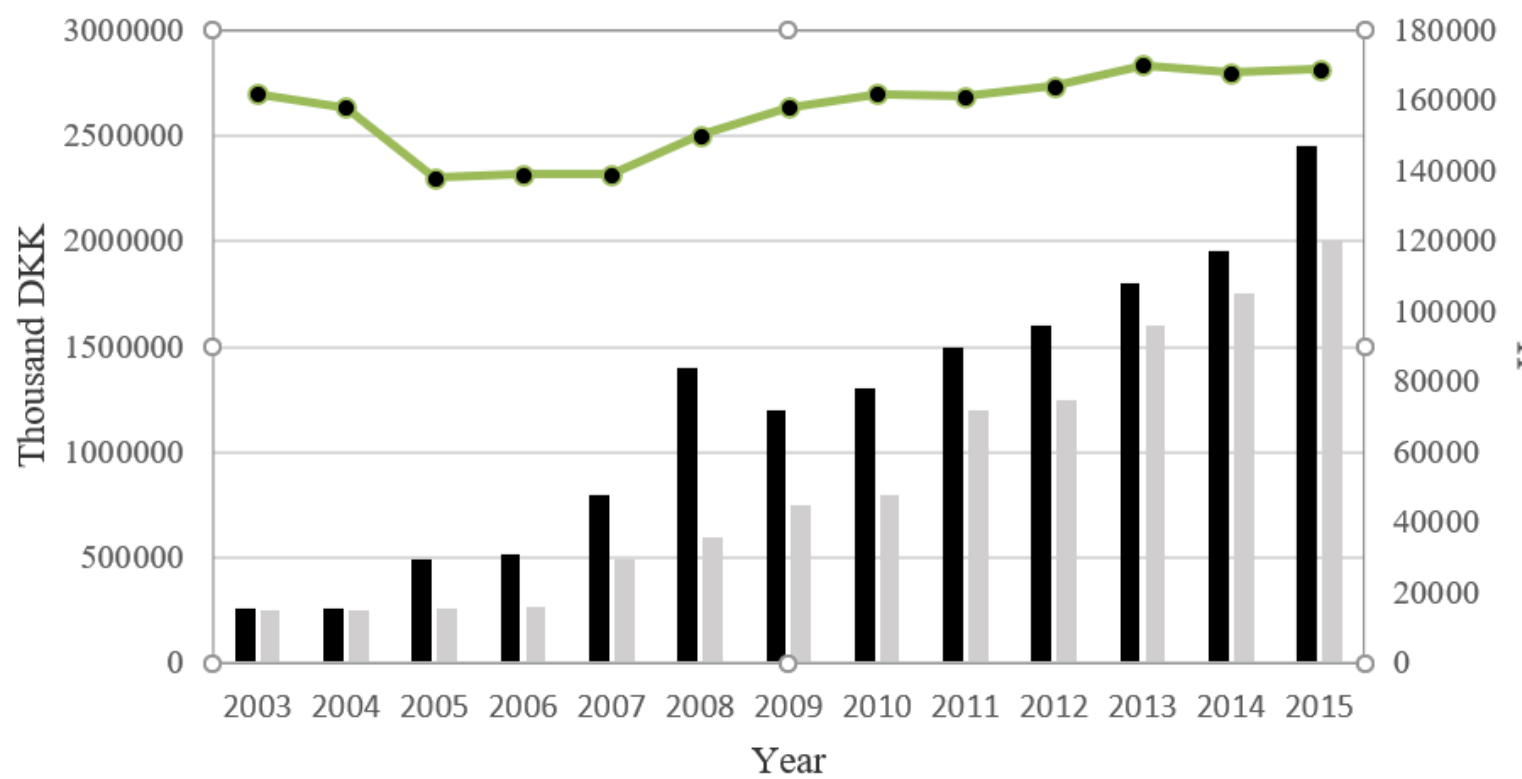

Organic import value $\quad$ Organic export value $\quad \bullet$ Organic land area

Figure 2. Evolution of organic land area, import value and export value in Denmark, 2003-2015, source: Brzezina et al., 2017, p. 13.

Financial support for organic farming, introduced by most countries in the 1990 s, initially translated into sharp quantitative growth measured with the area of organic farmland. In countries on a steep growth path, the growth rate varied in the range of $24 \%$ to $254 \%$. However, the increase in farmland was smaller than the faster growth in demand (Table 1). In 1999-2014, the cumulative increase in organic farmland was $292 \%$ whereas market growth was by 82 percentage points higher and reached $374 \%$. Some countries witnessed even larger gaps between the increase in organic farmland and market growth, for instance Germany (293 percentage points) and Austria (199 percentage points).
Table 1. Disparate development of production and markets. Source: Willer \& Lernound 2015.

\begin{tabular}{|l|c|c|}
\hline Country & $\begin{array}{c}\text { Cumulative } \\
\text { growth in } \\
\text { area 1999- } \\
2014(\%)\end{array}$ & $\begin{array}{c}\text { Cumulative } \\
\text { market growth } \\
1999-2014 \\
(\%)\end{array}$ \\
\hline Germany & 141 & 434 \\
\hline France & 254 & 383 \\
\hline Austria (2002-2013) & 24 & 223 \\
\hline Switzerland & 62 & 237 \\
\hline World (1999-2013) & 292 & 374 \\
\hline
\end{tabular}

In the relevant literature, not much research effort was dedicated to addressing the low share and the economic and environmental impacts of organic 
farming (Cristache et al., 2018; Khaledi et al., 2010). Meanwhile, that ratio reflects the position of organic farming which remains a niche in agricultural systems dominated by industrial farming. The small share of organic farming in global land resources has diverse environmental, economic and social consequences. In terms of sustainable development, this means a small contribution to the generation of environmental public goods and the failure to leverage the existing potential. From an economic point of view, the slower growth of organic farming, and the resulting fact that production grows slower than demand, means the market continues to be unsustainable. This results in what is referred to as the paradox of (low) supply which means that although the demand grows and the prices are high, the supply of organic food is small. Highly developed countries witness an increase in organic food imports which is of considerable importance to the environment as the public goods are generated outside the country concerned. African and Asian countries are among those which largely contribute to these imports. In these regions, demand for organic food is low and the area of organic farmland follows an upward trend; and, unlike in other countries, switching to organic production methods does not entail a decline in efficiency due to low agricultural intensity. In the UK, imports make up $70 \%$ of the organic food market (Morgan \& Murdoch, 1999, Barrett et al., 2002). In 2013-2014 alone, the number of organic food importers in the EU increased by $17 \%$. At the same time, the area of organic farmland grew by $1.1 \%$ and the number of organic farms reduced by $0.2 \%$ (Brzezina et al., 2017, p. 13). According to Danish data, in 2003-2015, organic product sales kept growing, imports dominated over exports, and the area of land under organic crops remained virtually unchanged. See Figure 2. The above has some specific environmental consequences because the pressure on imports increases food miles and contradicts the commitment to preserve the local nature of organic farming.

Another problem involved in an unsustainable market for organic food is the fact that product availability is limited both physically and economically. High prices are a prohibitive barrier to demand from most consumers, especially from those at low income levels. In this case, organic food has the characteristics of a luxury good available to high-income consumers. If the products are supplied to a small group of buyers and the farmers are subsidized with public funds, the consumers (taxpayers) may ask themselves about the objectives of and the rationale behind the support mechanisms used to transfer public funds to subsidize private goods of a small group of consumers.

A question arises about the reasons of the organic farming sector's poor position in the environmental, economic and social dimension, and especially about why it fails to make sufficient use of its potential ca- pacity to deliver environmental public goods. This capacity is largely the result of structural characteristics of agriculture which, on the one hand, define it as a sector which can be the source of public goods to the greatest extent, and on the other hand limit its rapid development. While the decision not to use chemicals in the organic farming system has positive externalities in the form of environmental public goods, it also reduces the economic efficiency of farming which is an important criterion of production decision-making. Structural characteristics of organic farming which reduce economic efficiency include high labor intensity (Schneeberger et al., 2002; Constance et al., 2010; Wheeler 2008). As the supply of labor in the rural labor market declines, and as there is strong pressure on wage growth, greater labor intensity increases the operating costs of organic farms (by 7-13\%) and makes them less competitive than their conventional peers (Crowder et al., 2015). Neither the high prices of organic food (private goods) nor the support for farmers in the delivery of public goods do sufficiently compensate for private losses resulting from the lower microeconomic efficiency of organic farming.

\section{Financial support for organic farming}

The challenge currently faced by organic farming is to strengthen its economic, environmental and social position. Due to its structural complexity and the role it may play in generating public goods, its future development will depend not only on internal but also on external factors which notably include public aid and financial support. The key conditions for strengthening the importance of organic farming include institutional support as a compensation for costs incurred by farmers in delivering environmental public goods. This is based on the assumption that an efficient government will better secure public goods than a market guided by individual needs (Czyżewski, Stępień, 2013, p. 36).

In the long run, the existing system for institutional support proved to be insufficient in making organic farming a sustainable sector. This testifies to the poor efficiency of the relevant government policy. In the European Union, since the 1990s, the Common Agricultural Policy (CAP) has pursued its commitment to strengthen the environmental goals through measures which include support for organic farming. However, at some point in time, the support mechanism became insufficient in preventing some farmers from discontinuing

organic production. For instance, the average discontinuation ratio for organic farmers in 2005 was $7.3 \%$ (Llorens Abando et al., 2007). A positive aspect is that following the 2013 CAP reform, support was provided for the first time under the $1^{\text {st }}$ and the $2^{\text {nd }}$ pillar of the CAP; this reflects the recognition of the organic farming's role in generating public goods. The modification of the existing CAP instruments 
Table 2. Key EU budget allocations for transitioning towards environmental and climate friendly practices and organic farming under the CAP 2014-2020, source: Stolze, 2016, p. 3.

\begin{tabular}{|c|c|c|c|}
\hline $\begin{array}{l}\text { Budget } \\
\text { Allocation }\end{array}$ & $\begin{array}{l}\text { Billion } \\
\text { Euro }\end{array}$ & $\begin{array}{l}\% \text { of total } \\
\text { EAFRD }\end{array}$ & $\begin{array}{c}\% \text { of total EU } \\
\text { budget for } \\
\text { agriculture }\end{array}$ \\
\hline \multicolumn{4}{|l|}{ Budget allocation for Pillar 1 and Pillar 2} \\
\hline $\begin{array}{l}\text { 1. Pillar } 1 \text { - European Argicultural Guarantee Fund (EAGF) - Market re- } \\
\text { lated expenditure \& direct payments (Commitment appropriation) }\end{array}$ & $€ 312.7$ & & $76 \%$ \\
\hline $\begin{array}{l}\text { 2. Pillar } 2 \text { - European Agricultural Fund for Rural Development } \\
\text { (EAFRD) - as adopted by EC }\end{array}$ & $€ 99$ & & $24 \%$ \\
\hline 3. Total EU budget for agriculture Pillar $1 \&$ Pillar $2[1+2]$ & $€ 411.7$ & & $100 \%$ \\
\hline \multicolumn{4}{|l|}{ Greening Component (Pillar 1) } \\
\hline 4. Total national ceilings for direct payments $2014-2010$ & $€ 297.6$ & & $72.3 \%$ \\
\hline 5. Greening component (maximum $30 \%$ of direct payments [4]) & $€ 89.3$ & & $21.7 \%$ \\
\hline \multicolumn{4}{|l|}{ Climate and environment issues (Pillar 2) } \\
\hline $\begin{array}{l}\text { 6. Contribution to environment \& climate issues - including organic } \\
\text { farming (minimum } 30 \% \text { of EAFRD [2]) }\end{array}$ & $€ 29.7$ & $30 \%$ & $7.2 \%$ \\
\hline \multicolumn{4}{|l|}{ Organic farming support (conversion and maintenance payments) } \\
\hline 7. EAFRD organic farming support (Measure 11) - as adopted by EC & $€ 6.3$ & $6.4 \%$ & $1.5 \%$ \\
\hline $\begin{array}{l}\text { 8. Total public expenditure (EU \& Member States) for organic farming } \\
\text { support (Measure 11) }\end{array}$ & $€ 9.9$ & & \\
\hline \multicolumn{4}{|c|}{ Total environmental and climate change spending for agriculture (Pillar 1 and Pillar 2) } \\
\hline $\begin{array}{l}\text { 9. EU budget for transition towards environmental and climate-friendly } \\
\text { agriculture }[5+6]\end{array}$ & $€ 119$ & & $28.9 \%$ \\
\hline
\end{tabular}

and the use of new ones gradually increase the role of production methods whose development has a positive climatic and environmental impact. This results from the commitment to agricultural and rural sustainability. Organic farms, just like their conventional peers, are provided with what is referred to as green direct payments under the $1^{\text {st }}$ pillar of the CAP (which focuses on supporting farming incomes and imposes certain requirements regarding environmental protection, animal welfare and food safety). Note however that unlike their conventional peers, organic farms are exempt from any additional requirements resulting from the pursuit of environmental goals. In the $2^{\text {nd }}$ pillar, which is about supporting rural development (RDP), organic farm subsidies are disbursed under the measure organic farming.

Although the European Union places more and more emphasis on environmental goals set under the $1^{\text {st }}$ and the $2^{\text {nd }}$ pillar of the CAP, two-thirds of funds in successive financial perspectives of the EU agricultural budget were allocated to conventional farming. This is also confirmed by the 2014-2020 financial perspective which seems to be dominated by support for conventional farming, the main beneficiary of the CAP. In the current financial perspective, direct support for conventional farming under the $1^{\text {st }}$ pillar alone is EUR 321.7 billion, whereas support for organic farming amounts to EUR 6.3 billion and represents $1.5 \%$ of the total agricultural budget of the European Union (Table 2). In turn, the amount of funds allocated to greening and to climatic and environmental measures in agriculture is EUR 119 billion (with a share of $28.9 \%$ in the agricultural budget). According to Stolze the bulk of expenditure, almost two-thirds of the EU budget for agriculture, is therefore dedicated to achieving other goals, which are not linked to either environmentally and climate-friendly farming practices or sustainable farming systems and to which the EU still gives higher priority. Thus, despite the efforts made with the 2013 CAP reform, the EU is not yet clearly signaling to farmers that these approaches are a priority (Stolze et al., 2016, p. 10).

Compared to the previous financial perspective, the contribution of organic farming to the delivery of public goods is now met with greater recognition as it is also supported under the $1^{\text {st }}$ pillar of the CAP. However, that support is available to all other farms which meet the defined criteria, including those which continue using pesticides that generate negative externalities. In 2014-2020, member countries differed in their approach to organic farming payments which depend on farmland type, crop type and farming intensity. The share of support for organic farming in the EU's total agricultural budget differed between the countries, ranging from $0.2 \%$ (Malta) to $13.2 \%$ (Denmark). Although most member countries increased their payment rates for organic farms compared to the previous financial perspective, some of them witnessed stagnation (growth of $0.4 \%$ in Portugal) or decline in organic farmland (by $26.4 \%$ in the UK and $12.3 \%$ in Poland) in 20142018 (no data is available for 2019-2020). During some years, a transitory reduction was experienced in five EU countries (Denmark, Ireland, Greece, Romania and Hungary). The above suggests that support is an insufficient measure in stimulating the development of organic farming and strengthening its position in agricultural systems. This means that in the context of market imperfections - and in the absence of valuation of public goods - microeconomic 
costs incurred by organic farmers continue to exceed the benefits they reap. The level of support must be high enough to stimulate the development of organic farming in the long run. Otherwise, it will be a highly volatile business affected by fluctuations in the growth trend. Therefore, it is recommended that the future support mechanism provide financial encouragement for organic farming, revise the principles for granting payments, tighten the system, and minimize the amount of payments decoupled from production volumes. Public money for public goods, a slogan that guided the 2013 CAP reform, also means a commitment to take measures focused on eliminating unfair practices whereby organic payments are used by farmers who do not engage in organic farming on a permanent basis (as it is the case for Polish organic orchards payments).

In addition to financial aid, organic farmers also need technical and innovativeness support to improve their economic competitiveness and introduce solutions that make this sector more efficient and sustainable. This is a condition for improving the cost efficiency which, if not satisfactory, will make it very difficult to exit the niche in the future. Considerable opportunities in this field are provided by the new instrument of the institutional environment, namely the European Innovation Partnership Agricultural Productivity and Sustainability (EIP-AGRI) adopted by the European Commission in 2012. It assumes that the organic sector should be included in a larger systemic flow of knowledge and innovations based on a partnership between science and practical uses. Due to its structural complexity, the organic farming sector is in an incessant need for knowledge and innovation related to crop optimization methods, improvements in productivity, fertilization, soil fertility management etc. Relevant enhancements of the institutional environment of organic farming, based on cooperation and increased exchange of knowledge and experience between different actors, provide new opportunities for accelerated growth. If effectively stimulated, it will be determinant for the future role of organic farming in implementing sustainable development principles.

\section{Conclusion}

Organic farming has a small share in total farmland, and therefore its potential capacity to deliver public goods is not fully tapped into. This undermines the importance of organic farming in implementing the principles of sustainable agricultural and rural development. High prices of, and growing demand for, organic food are not enough to stimulate the growth of organic farming. Hence, the root causes of the low supply paradox should not be sought among market factors. Instead, it can be explained by the structural characteristics of organic farming and in the economic consequences of its complexity, i.e. high costs and lower production profitability. Financial support has for some time been the key driver of organic farming development. However, for several years now, many European Union countries have periodically experienced a transitory or a years-lasting decline in the area of organic farmland. This reflects the exhaustion of the existing growth potential of organic farming in the context of the current support mechanism. To strengthen its position and achieve the desired goals related to the delivery of public goods, more effective amendments need to be made to the CAP as the main support instrument so it may ensure the development and sustainability of organic farming in the future. The key role in this regard will be played by the government policy and its impact on the formation of the institutional environment that stimulates production methods which generate positive agricultural externalities.

\section{References}

1. AOCELLA N., 2002, Zasady polityki gospodarczej, PWN, Warszawa.

2. ALTVATER E., 2007, Public goods for human security, in: Papeles del Ester, 14, http://revistas.ucm.es/ index.php/PAPE/article/viewFile/PAPE0707220001 A/25673, (23.03.2020).

3. BARRETT H. R., HARRIS P. J.C., BROWNE A.W., CADORET K., 2002, Organic certification and the UK market: Organic imports from developing countries, in: Food Policy, 27(4), p. 301-318.

4. BENGTSSON J., AHNSTROM J., WEIBULL A.-C., 2005, The effects of organic agriculture on biodiversity and abundance: A meta-analysis, in: Journal of Applied Ecology, 42, p. 261-269.

5. BRODZIŃSKA K., 2015, Renta polityczna ziemi w aspekcie dóbr publicznych - ujęcie teoretyczne i empiryczne, in: Zeszyty Naukowe Szkoły Gtównej Gospodarstwa Wiejskiego Ekonomika i Organizacja Gospodarki Żywnościowej, 109, s. 43-53.

6. BRZEZINA N., BIELY K., HELFGOTT A., KOPAINSKY B., VERVOORT J., MATHIJS E., 2017, Development of Organic Farming in Europe at the Crossroads: Looking for the Way Forward through System Archetypes Lenses, in: Sustainability, 9, p.13.

7. CONSTANCE D.H.; CHOI J.Y., 2010, Overcoming the barriers to organic adoption in the United States: A Look at pragmatic conventional producers in Texas, in: Sustainability, 2, p. 163-188.

8. COOPER T., HART K., BALDOCK D., 2010, The provision of public goods through agriculture in the European Union, Report prepared for DG Agriculture and Rural Development, Contract No 30-CE0233091/00-28, Institute for European Environmental Policy, London.

9. COUNCIL REGULATION (EEC), 1991, Regulation no 2092/91 of 24 June 1991 on organic production of agricultural products and indications referring thereto on agricultural products and foodstuffs, OJ L198 of 22 July 1991, p. 1.

10. CRISTACHE S-E., VUTA M., MARINE., CIOACA S-J., VUTA M., 2018, Organic versus Convetional Farming - A Paradigm for the Sustainable Development of the European Countries, in: Sustainability, 10, p.1-19. 
11. CROWDER D.W., REGANOLD J.P., 2015, Financial competitiveness of organic agriculture on a global scale, in: Proceedings of the National Academy of Sciences USA, 112, p. 7611-7616.

12. CZYŻEWSKI A., STANISZEWSKI J., 2018, Dylematy operacjonalizacji paradygmatu zrównoważonego rozwoju rolnictwa z wykorzystaniem pojęcia ekoefektywności, w: Problemy Rolnictwa Światowego, 18(2), p. 440-445.

13. CZYŻEWSKI A., STĘPIEŃ S., 2013, Ekonomicznospołeczne uwarunkowania zmian paradygmatu rozwoju rolnictwa drobnotowarowego w świetle ewolucji Wspólnej Polityki Rolnej, w: Problemy Drobnych Gospodarstw Rolnych, 2, p. 25-39.

14. DE BUCK A., v. RIJN I., ROLING N., WOSSINK G., 2001, Farmers' reasons for changing or not changing to more sustainable practices: an exploratory study of arable farmers in the Netherlands, in: The Journal for Agricultural Extension and Education, 7(3), p. 153-166.

15. EUROPEAN COMMISSION, 2004, 415 final. European Action Plan for Organic Food and Farming, Brussels, 10.06.2004.

16. HALL C., VITTIE MC A., MORAN D., 2004, What does the public want from agriculture and the countryside?, A review of evidence and methods, in: Journal of Rural Studies, 20, p. 211-225.

17. JESPERSON L., BAGGESEN D., FOG E., HALSNAES K., HERMANSENL., ANDREASENL., STRANDBERG B., SORENSEN J., HALBERG N., 2017, Contribution of organic farming to public goods in Denmark, in: Organic agriculture, 7, p. 243-266.

18. KHALEDI M., LIAGHATI H., MOHAMMADAMINI M., S. VESEN S., 2010, Assessing barriers to conversion to organic farming in Canada, in: Journal of Environmental Sciences 2(4), p. 109-126.

19. LLORENS ABANDO L., ROHNER-THIELEN E., 2007, Different Organic Farming Patterns within EU-25: An Overview of the Current Situation, Statistics in Focus, Eurostat, http://epp.eurostat.ec.europa.eu/cache/ITY_OFFPUB/KS-SF-07-069-N.PDF

20. MICHELSEN J., LYNGGAARD K., PADEL S., FOSTER C., 2001, Organic farming Development and Agricultural Institutions in Europe: A Study of Six Countries. Organic Farming in Europe: Economics and Policy, 9, University of Hohenheim 2001.

21. MIDMORE P., PADEL S., MC CALMAN H, N. H. LAMPKIN, FOWLER S., ISHERWOOD J., 2001, Attitude to Organic Production: a survey of producers. Un published final report to MAFF, Institute of Rural Studies, University of Wales, Aberystwyth.

22. MORGAN K. \& MURDOCH J., 2000, Organic vs. Conventional Agriculture: Knowledge, Power and Innovation in the Food Chain, in: Geoforum, 31, p. 166.

23. NIGGLI U., 2015, Sustainability of organic food production: Challenges and innovations, in: Proceedings of the Nutrition Society, 74, p. 83-88.
24. SAMUELSON P., NORDHAUS W., Ekonomia, PWN, Warszawa 1996.

25. SCHNEEBERGER W., DARNHOFER I., EDER M., 2002, Barriers to the adoption of organic farming by cash-crop producers in Austria Barriers to the adoption of organic farming by cash-crop producers in Austria, in: American Journal of Alternative Agriculture, 17, p. 24-31.

26. STIGLITZ J.E., 2004, Economics of public sector, W.W. Norton, New York.

27. STOATE C., BALDI A., BEJA P., BOATMAN N., HERZON I., VAN DOORN A., RAKOSY L., RAMWELL C., 2009, Ecological impacts of early 21st century agricultural change in Europe - a review, in: Journal of Environmental Management, 91(1), p. 2246.

28. STOLZE M., LAMPKIN N., 2009, Policy for organic farming: Rationale and concepts, in: Food Policy, 34, p. 237-244.

29. STOLZE M., SANDERS J., KASPERCZYK N., MADSEN G., MEREDITH S., 2016, CAP 20142020. Organic farming and the prospects for stimulating public goods, IFOAM EU, Brussels.

30. TITTONELL P., 2014, Ecological intensification of agriculture-sustainable by nature, in: Current Opinion in Environmental Sustainability, 8, p. 53-61.

31. TUOMISTO H.L., HODGE I.D., RIORDAN P., MACDONALD D.W., 2012, Does organic farming reduce environmental impacts? - A meta-analysis of European research, in: Journal of Environmental Management, 112, p. 309-320.

32. UNNEVEHR L., 2004, Mad cows and Bt potatoes: global public goods in the food system, in: American Journal of Agricultural Economics, 5(86), p. 11591166.

33. WHEELER S., 2008, The barriers to further adoption of organic farming and genetic engineering in Australia: Views of agricultural professionals and their information sources, in: Renewable Agriculture and Food Systems, p. 161-170.

34. WILLER H., LERNOUD J. (eds.), 2015, The World of Organic Agriculture. Statistics and Emerging Trends 2015, Research Institute of Organic Agriculture (FiBL), Frick and IFOAM Organics International, Bonn, https://www.organic-world.net/yearbook/yearbook2015/pdf.html, (23.03.2020).

35. WILLER H., SCHLATTER B., Jan TRAVNICEK J., KEMPER L., LERNOUD J., 2020, The World of Organic Agriculture Statistics and Emerging Trends 2020, Research Institute of Organic Agriculture (FiBL), Frick and IFOAM Organics International, Bonn, https://www.organic-world.net/yearbook/year book-2020.html, (23.03.2020).

36. WOJTYNA A., 1990, Nowoczesne państwo kapitalistyczne a gospodarka, Teoria i praktyka, PWN, Warsaw. 